\title{
Fashion Magazines and Fashion as a System of Magic
}

\author{
Moeran, Brian
}

Document Version

Final published version

Publication date:

2015

\section{License \\ CC BY-NC-ND}

Citation for published version (APA):

Moeran, B. (2015). Fashion Magazines and Fashion as a System of Magic. Paper presented at The American Anthropological Association Annual Meeting 2015, Denver, United States.

Link to publication in CBS Research Portal

\section{General rights}

Copyright and moral rights for the publications made accessible in the public portal are retained by the authors and/or other copyright owners and it is a condition of accessing publications that users recognise and abide by the legal requirements associated with these rights.

\section{Take down policy}

If you believe that this document breaches copyright please contact us (research.lib@cbs.dk) providing details, and we will remove access to the work immediately and investigate your claim. 


\title{
Fashion Magazines and Fashion as a System of Magic
}

\author{
Brian Moeran
}

\section{Prolegomenon}

This article is about international women's fashion magazines-specifically Elle, Harper's Bazaar, Marie Claire and Vogue-and the part they play in creating and sustaining the fashion industry as a system of magic. ${ }^{1}$ That it is indeed a system may be seen in the fact that, as with other systems of magic, the fashion industry makes use of magicians, magical rites, and magical representations (Mauss 1972: 18; see also Malinowski 1922: 403).

Fashion magazines are an integral part of the fashion industry, and adopt numerous magical practices to enchant their readers into desiring, if not buying, fashionable clothing of all sorts, together with accessories (handbags, shoes, scarves, jewellery, and perfume), and beauty products advertised in their pages (Spin a magic spell in dreamy dresses, cool capes and beyond-the-veil headpieces). (Figure 1) These practices consist of textual and visual enchantments enacted by editors, photographers, stylists, art designers, makeup artists, and hair stylists employed by fashion magazines, as well as by the fashion and beauty companies advertising therein, and by the fashion designers whose work they portray. As such, fashion magazine practices parallel those found in magical and religious rites in general: they tend to have different agents performing them; and their performances take place in different locations and in different circumstances (secretly, in the case of studio fashion shoots; or in public, as with the six-monthly cycle of fashion collections) (Mauss 1972: 24).

Fashion magazines make use of professional magicians, whose rites and spells are behind the fantasies (the fantasy of this gently distressed style), seduction (prints with a seductive touch), and transformations (Vixens who transform a black le smoking with a slick of merlot gloss) characterising the fashion and beauty industries (Lipovetsky 1994; 
Entwistle 2000). ${ }^{2}$ Together, they form a "magical worldview" (Wax and Wax 1963) in which spells, rituals, and elixirs charm, bewitch, mesmerize, captivate, and entice readers of fashion magazines with an alchemy of refined and powerfully addictive contrasts designed to give them irresistible allure and a mysterious or seductive aura. ${ }^{3}$

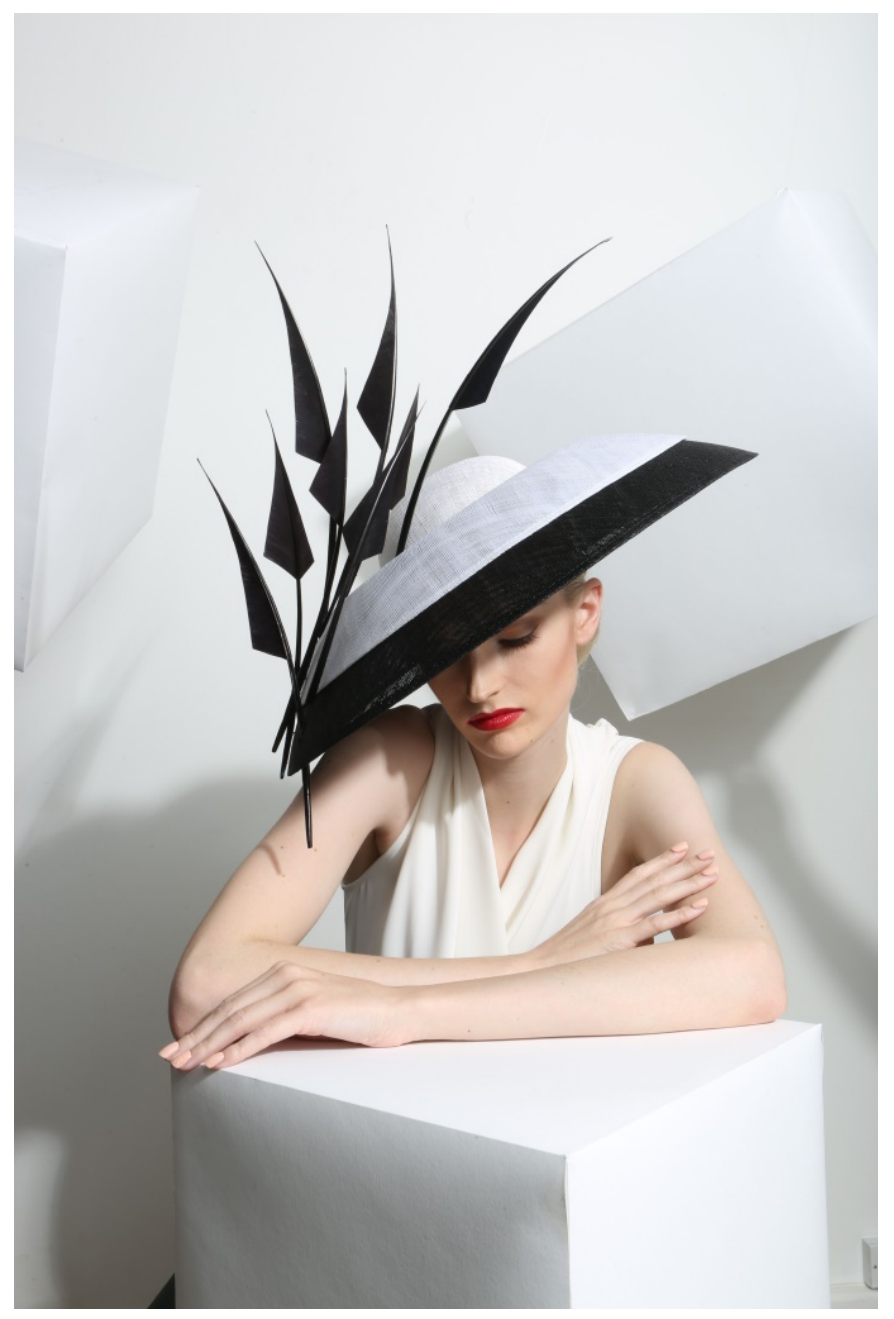

Figure 1: Dreamy dress and enchanting beyond-the-veil headpiece (Helena Greyhorse, photographed by Kurtiss Lloyd, with makeup by Silvia Ileana Stella. Courtesy of Philip Treacy)

\section{Fashion, Magic and Fame}

The word "magic" refers to a broad range of beliefs that includes the supernatural, superstition, illusion, trickery, miracles, and fantasies (Davies 2012: 1). It is also one of the oldest subjects of discussion and theorizing in anthropology. From time to time, anthropologists, as well as scholars from other disciplines, have suggested that magic is 
not specific to "primitive" societies, but is to be found at work in contemporary industrialised societies-in practices as disparate as advertising (McCreery 1995) and financial derivatives (Appadurai 2016).

The idea that fashion (or clothing) is a form of magic is not new, either. More than half a century ago, John Flügel (1950: 72) argued that it was initially their magical, rather than ornamental or decorative, properties that gave articles of clothing a meaning beyond their functional use. For her part, Elizabeth Wilson (1987: 21) noted that "dress, like drama, is descended from an ancient religious, mystical and magical past of ritual and worship... Even today garments may acquire talismanic properties" (French chanteuse Soko has a recording studio talisman: a pair of red vintage Dr. Martens). ${ }^{4}$

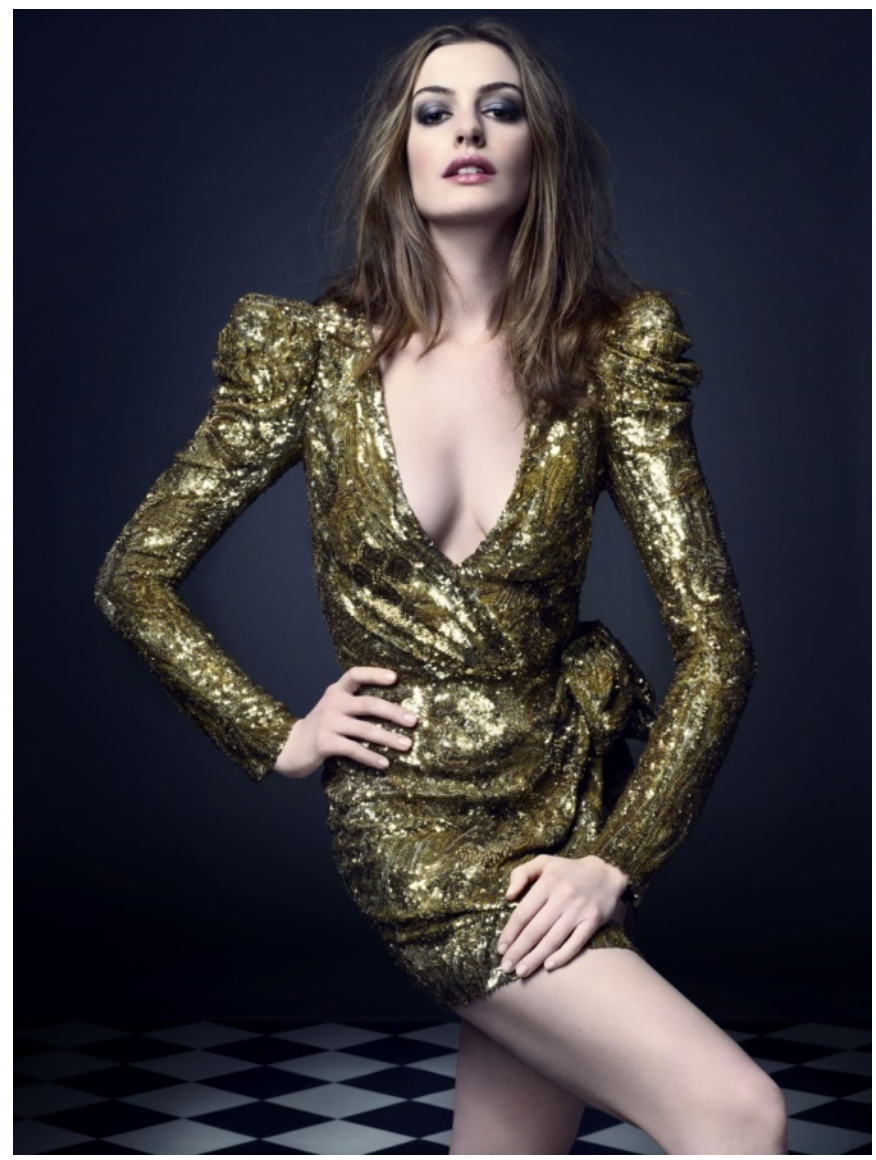

Figure 2: Lashings of Lurex add film star glamour (Anne Hathaway by David Slijper for Elle UK, December 2010).

An obvious link between magic and fashion, much used by English language fashion magazines, is glamour-an old Scottish word, gramyre, meaning "magic, 
enchantment or spell." It came into English in the early 1800s to mean "delusive or alluring charm," and has since come to refer to "an enticing image, a staged and constructed version of reality that invites consumption" (Gundle and Castelli, 2006: 3-4, 8). As visual deception, glamour is the essential ingredient of fashion and celebrity (lashings of Lurex add film star glamour) (Figure 2), both of which are based on an "enchanted fabrication of images of seduction" (Lipovetsky 1994: 182).

Just how glamour works, though, is never quite certain. The function of fashion magazines is to overcome this uncertainty, generally by one of two means. First, they make use of a language which refers either directly, or indirectly, to the realm of magic, in both fashion story headlines (Magic in the Moonlight) and vocabulary (alchemy, allure, aura, bewitchment, captivation, charm, enchantment, illusion, sorcery, and spells). By bringing magic into the open, fashion magazines make it-and fashion itself-seem real and not illusory (There is nothing quite as iconic as a classic Chanel tweed piece... Its texture, its weight, and its very aura are the things magic is made of). In other words, they do not describe clothing or dress so much as perform fashion (Austin 1975; Today's grunge is a softer, more wearable trend than before). ${ }^{5}$ (Figure 3)

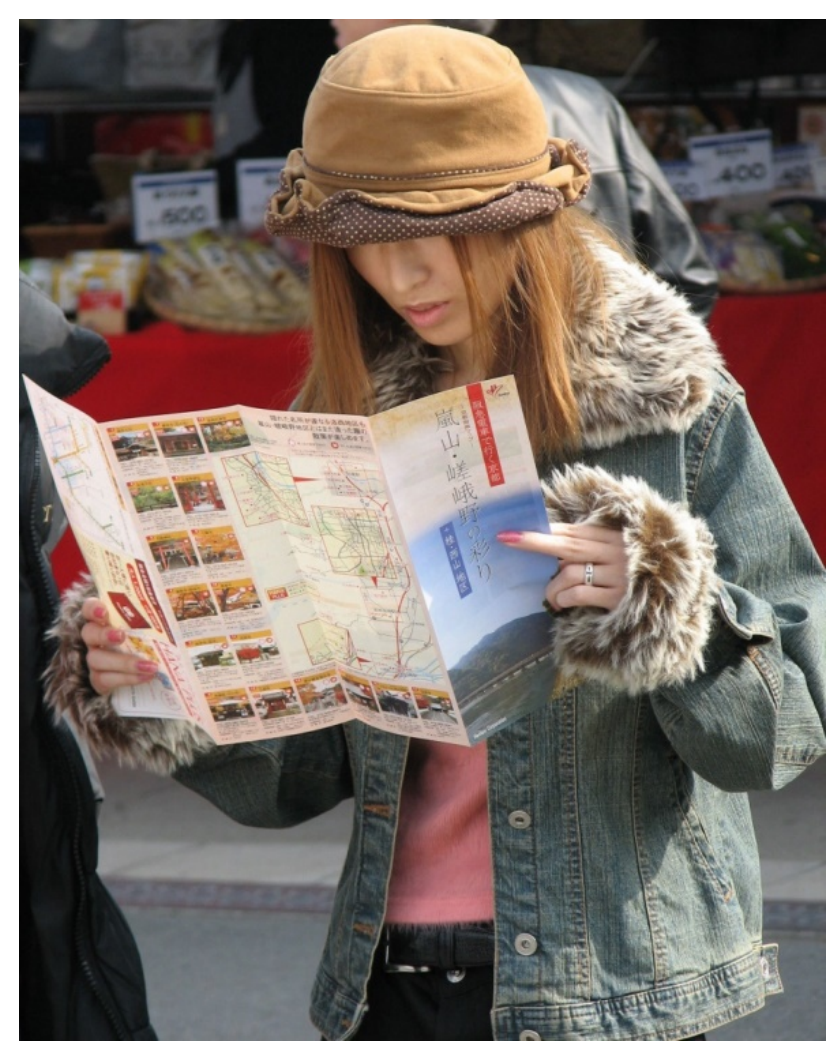

Figure 3: Today's grunge is a softer, more wearable trend than before (photo by Brian Moeran). 
Second, fashion magazines use names in support of their performative language and images. ${ }^{6}$ Names fix meanings "by transposing them into terms of other significations" (Lévi-Strauss 1966: 172), so that

"What is in a name is a potentiality, not only to re-present reality to ourselves in a form that makes it less anxiety-provoking, less refractory to control, but to act more confidently in situations that are unpredictable, dangerous and subject to a high degree of uncertainty" (Jackson 2005: 79).

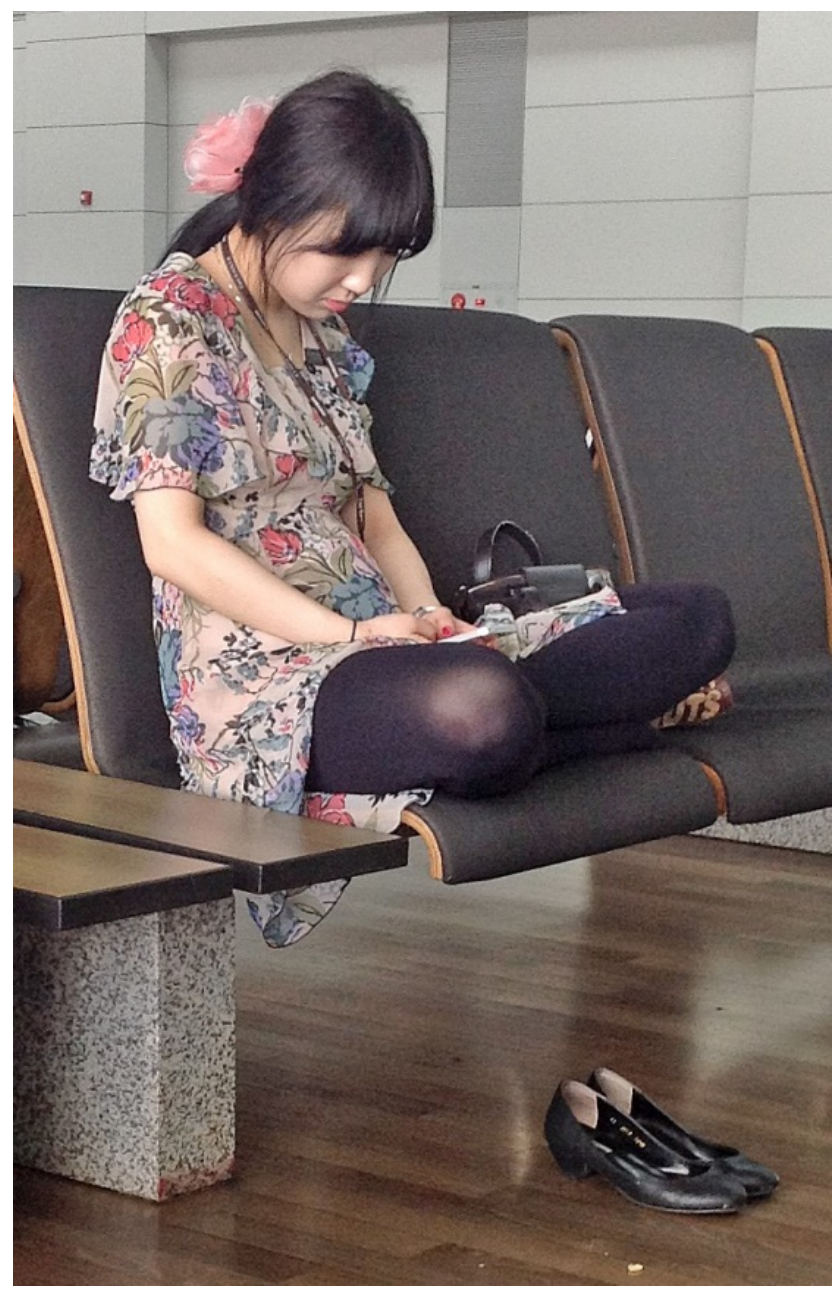

Figure 4: The shoe du jour is the new flat (photo by Brian Moeran).

Fashion magazines participate in naming processes in two ways: by creating equivalence between concept and form in the rhetoric of fashion (The shoe du jour is the new flat) (Figure 4) and by bringing names from different realms together seamlessly in readers' minds (Hilary Clinton in Oscar de la Renta). They also turn fashion designers 
into celebrities by showing their readers who's wearing what, made by whom, for what occasion, where and with whom (who is also wearing what, made by whom, etcetera) (Lopez sparked a craze for Timberland-inspired Manolo Blahnik booties). This process of osmosis is carried over into the rest of the fashion world, where photographers, models, makeup artists, hair stylists, and other "gurus" are all thrust into the celebrity spotlight (Here's how the costume designers, hair stylists, and makeup artists make the magic happen). The photographs, the gossip, the clothes, the accessories, the makeup, the hair, and perfumes together create the illusio that sustains both fashion and stardom (Morin, 1972: 79). This is sympathetic (or homeopathic) and contagious magic (Frazer 1990:

11) at its most effective.

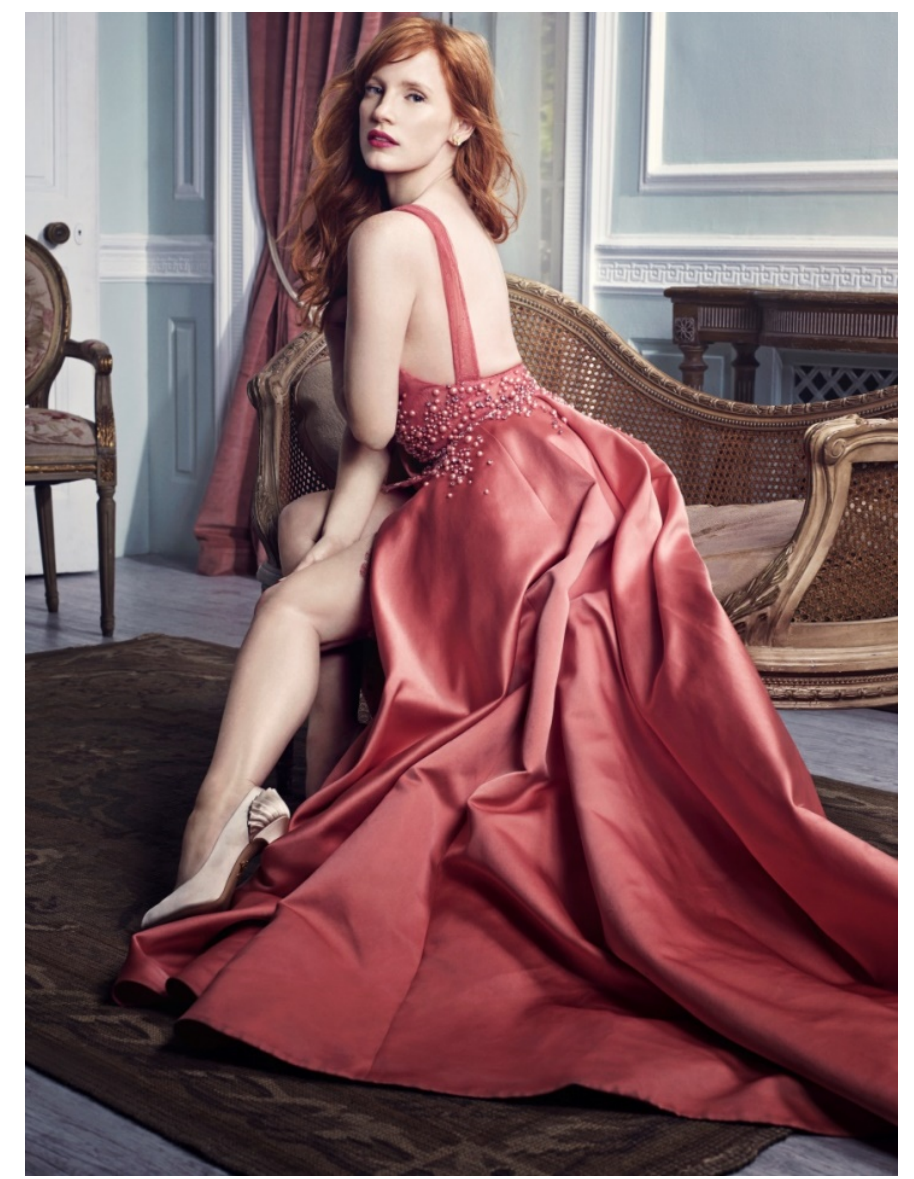

Figure 5: Evening wear with red carpet appeal (Jessica Chastain by David Slijper, for Harper's Bazaar UK. November 2014).

The system of fame sustained by fashion magazines is thus a transactional process (Munn 1986: 107) made up of three elements: a (celebrity's) body that wears a dress (Jessica Chastain in Dior Haute Couture); "an attached material décor" (the item 
itself ; beaded silk jacquard dress), which "adds a seductive intensification of beauty to that of the body"; and "a noise" (or buzz) that accompanies both body and material dress (evening wear with red carpet appeal), so that "what may be out of sight may nevertheless be heard" (Munn 1986: 114). Magazines sustain their readers' belief in fashion through other people's experiences contained in the stories they publish (Evans Pritchard 1937: 477). Celebrities verify that magic works (Jessica Chastain's spellbinding presence). (Figure 5)

\section{Technologies of Enchantment}

In order to understand the values, myths, and beliefs found in fashion-as-magical system, I am going to follow Alfie Gell $(1988,1992)$ in considering fashion and beauty as "components of technology." In other words, as a category, the fashion magazine is the outcome of technical processes (writing, editing, design, photography, styling, modelling, and so on) which, like certain forms of art, have as their unified aim the making of beauty and style. Together, they are part of a gigantic technical system formed by the fashion and beauty industries, which make use of what Gell (1992: 43) calls technologies of enchantment.

To keep a complex intellectual argument simple, the power of fashion's clothing and accessories stems from the technical processes they embody. This means that technologies of enchantment are founded on our enchantment with technology: "the power that technical processes have of casting a spell over us so that we see the real world in an enchanted form" (Gell 1992: 44). Fashion and beauty provide "one of the technical means whereby individuals are persuaded of the necessity and desirability of the social order which encompasses them" (ibid.).

Enchantment is integral to all sorts of fashion- and beauty-related activities, and is practiced by an ensemblage of magical actors who are both enchanted by, and who utter their spells of enchantment over, the magical world in which they operate (Play dress up in seductive partywear that pairs dazzling prints and glittering finishes for a spellbinding look. The bewitching hour is now...). ${ }^{7}$ In other words, the power of fashion lies in the performative and symbolic processes surrounding clothing-as-fashion items, rather than in the items themselves, even though it is these that are exhibited, commented on, bought and sold (A sleek tuxedo jacket lends Martine Sitbon's delicately distressed dress a structured edge). ${ }^{8}$ 
These magicians of fashion and beauty use technologies of enchantment as a means of persuasion, since they entice us to see what might (or again, might not) be a naked king wearing fine clothes (disguise your flaws). Like the canoe prow-boards used by the kula flotilla in the Trobriand Islands, fashion is not dazzling as a physical object so much as "a display of artistry explicable only in magical terms, something which has been produced by magical means" (Gell 1992: 46; Broad shoulders create the illusion of a small waist). (Figure 6) It is how a fashion has come into existence-its becoming, rather than its being (Wild-and-woolly shearling will be worn by leaders of the pack as the mercury plummets)-that is the source of its power over us.

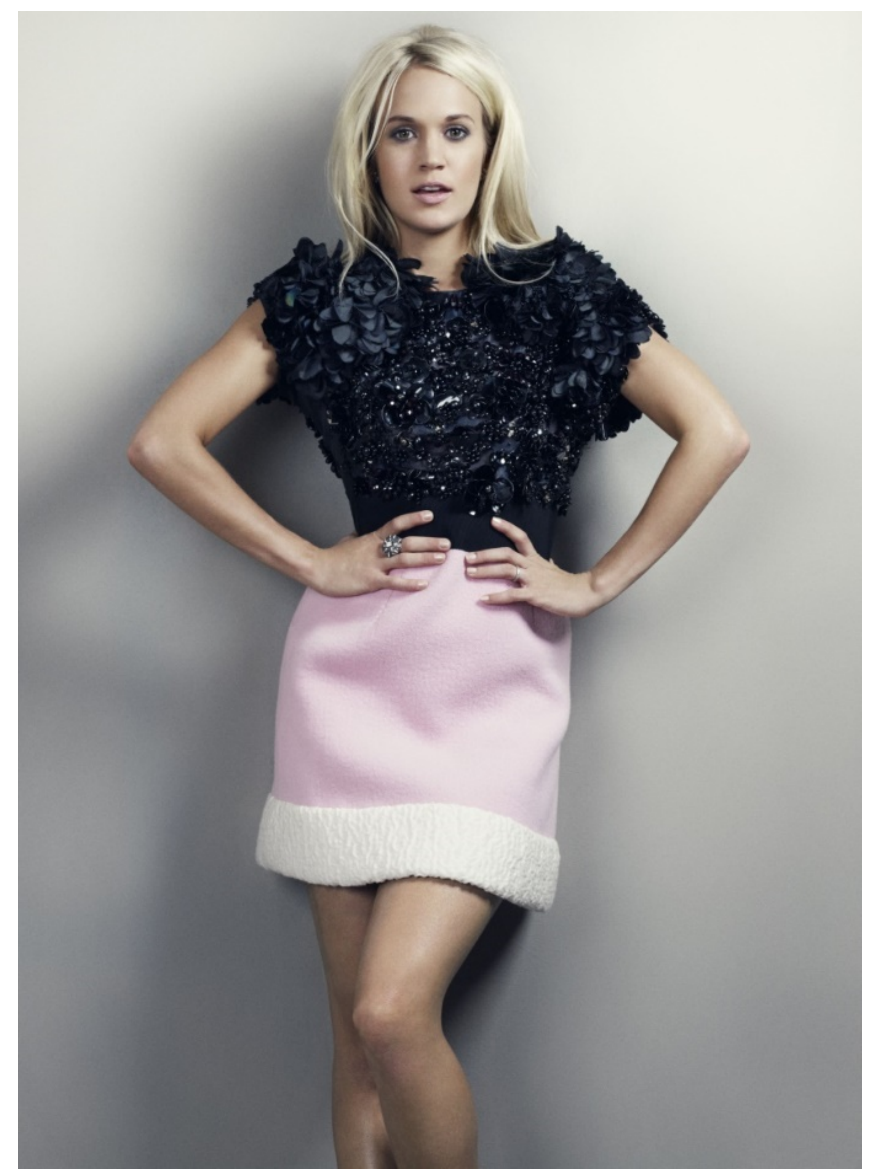

Figure 6: Broad shoulders create the illusion of a small waist (Carrie Underwood by David Slijper, for InStyle, December 2010).

\section{Magicians, Rites and Representations}

As noted earlier, magic as a system consists of three elements: magicians, magical rites, and magical representations. Together these enable four things to take place. First, certain qualities are transferred from objects to people by means of similarity and 
contiguity. Second, certain "nondiscoursive, embodied acts" persuade the followers of fashion that their performers' words and deeds are effective. Third, performers engaged in such magical practices are seen to possess exceptional and charismatic personal characteristics. And fourth, the magic used "provides evidence of contact with transcendental forces" (Dion and Arnould 2011: 504).

Among the magicians are the fashion designers (Der Magier), who, like doctors, blacksmiths, actors, and other skilled craftsmen, are seen to possess magical powers and weave magical effects. (Figure 7) They can accomplish things beyond the power of normal human beings (Amy Adams enchants at Max Mara), which is why they are often described as "sorcerers," "wizards," and "shamans" (Moeran 2014: 131-6). "It is their profession which sets them apart from the common run of mortals, and it is this separateness which endows them with magical power" (Mauss 1972: 29).9

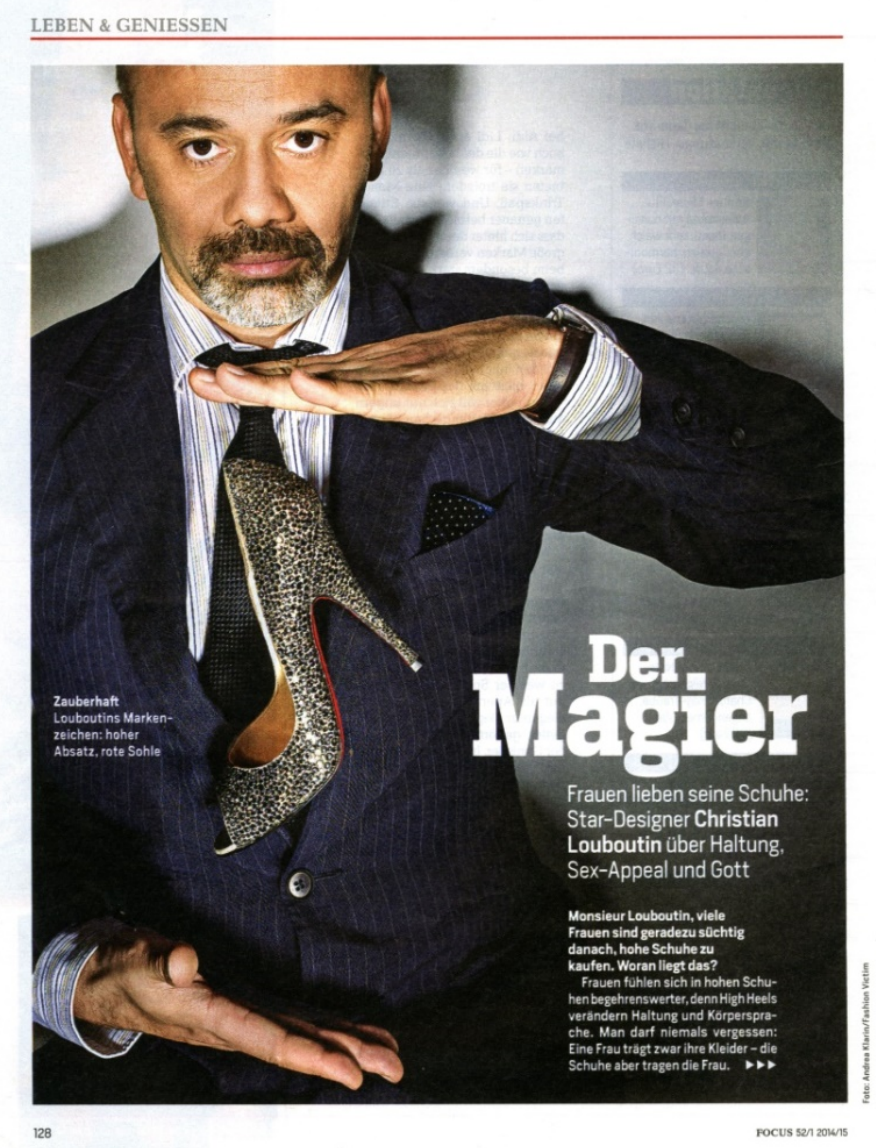

Figure 7: Shoe designer as über-magician (Christian Louboutin by Andrea Klarin, for Focus 2014/2015).

A designer, then, is "half-technician and half-mystagogue" (Gell 1992: 59). Precisely because the ordinary technical means s/he employs point inexorably towards 
magic (the designer used trompe l'oeil to add a necklace to a sweater), fashion itself becomes enchanted (as though the dresses were emerging from some enchanted forest). (Figure 8) We stand in awe of fashion, seeing it as an idealized form of production because we're at a loss to explain how it comes to exist in the first place (Gell 1992: 612).

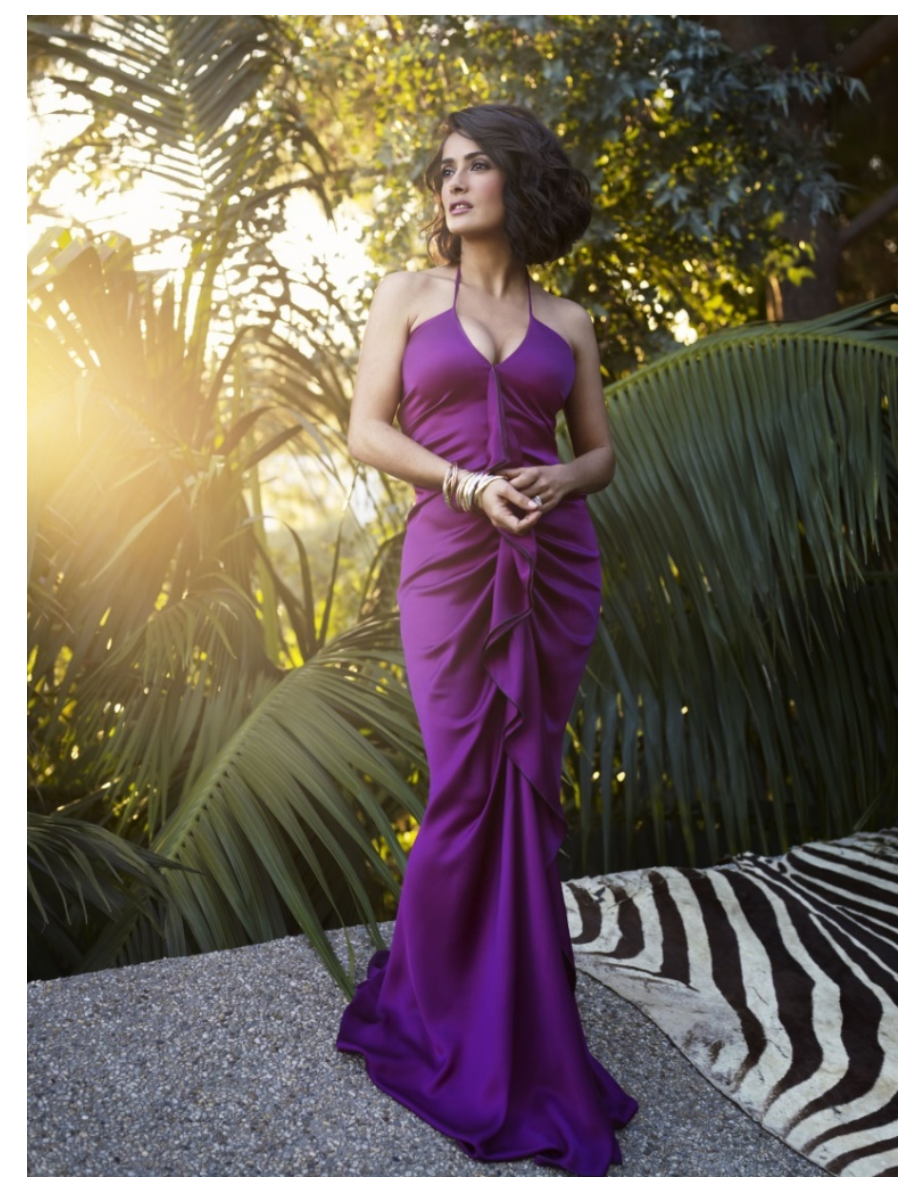

Figure 8: As though the dress were emerging from some enchanted forest (Salma Hayek by David Slijper, for InStyle, June 2010).

Like magic in general, fashion tends not to be performed just anywhere, but in specially qualified places, with special materials and tools, at special times of the year. Fashion's magicians take part in the regular display of formal, normative, and ceremonial collections-magical rites, during which they reproduce their charismatic authority (Dion and Arnould 2011: 508-9; the collection was simply fabulous) by bringing about transformations (summer's peacock feather skirt had morphed into a coq feather cape) in a liminal space between themselves and their audience of celebrities, critics, buyers, and the fashion press. By reporting the collections shown during the 
fashion weeks in New York, London, Paris, and Milan, fashion magazines consecrate designers, celebrities, the fashion world, and fashion itself: close up, customers will be able to see tweed glittering like the knit worn by front-row guest Diane Kruger (Entwistle and Rocamora 2011; see also Bourdieu 1993: 120-5). (Figure 9)

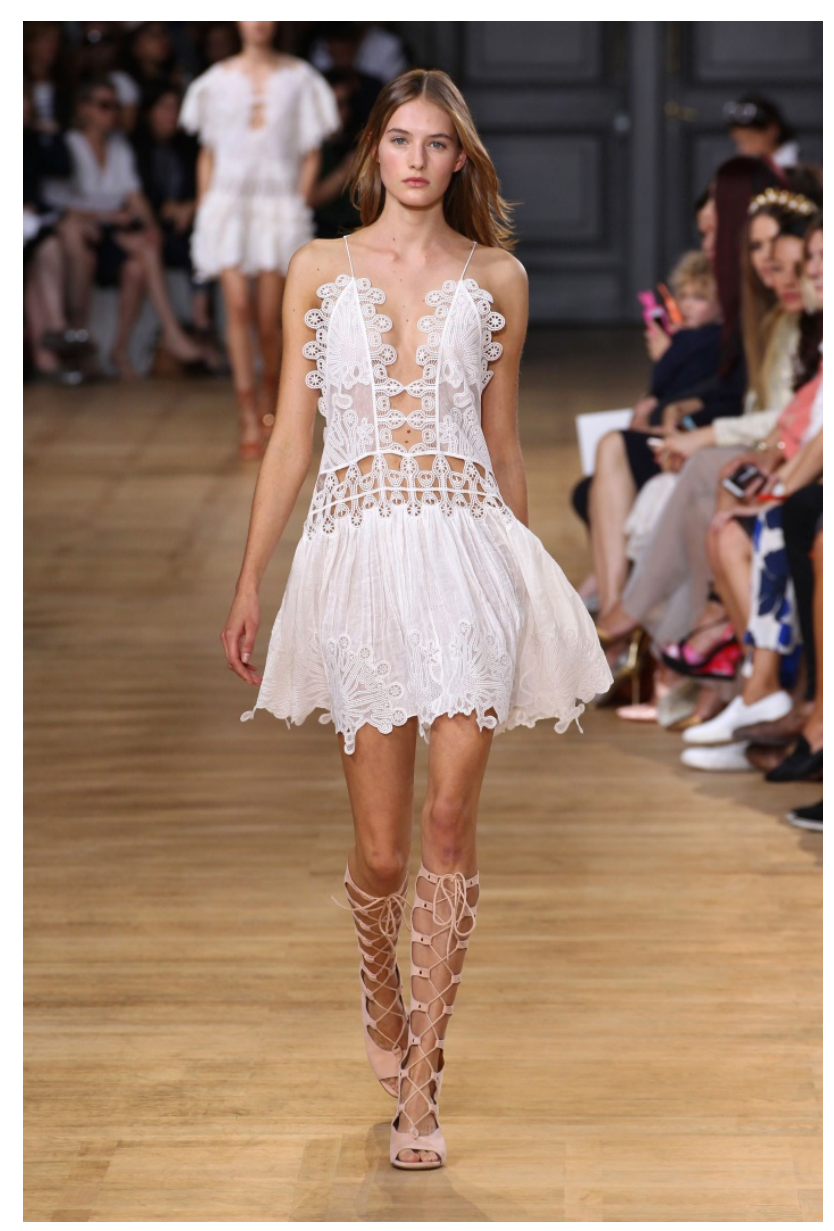

Figure 9: The collection was simply fabulous (photo courtesy of Chloé).

Magical representations, the third element in the system of magic, "are those ideas and beliefs which correspond to magical actions" (Mauss 1972: 61). Fashion magazine editors act as medium between magicians and their audience by brokering catwalk images, and by adding many more studio and location photographs to promote and legitimate "trends" (Crane 2000: 165; The trend: new sexy-provocative, subversive and with a dash of S\&M style). They also translate ideas and representations of ideas into a discourse of fashion, or "F words" (Steele 1991), usually depicting a change of state (metallic rings give an added sharpness). (Figure 10) Fashion magazines tend either to describe an item of dress or its wearer in such a way that certain movements, accidents 
or phenomena will inevitably occur (create cleavage with a demi underwire bra), or they promise to lead them out of a dangerous state (hide full hips ...) by means of a particular remedy (...with a roomy, knee-length skirt). They thus echo a general effect of magic, whereby "the normal state of human beings can, if once lost, be regained by magic and by magic only" (Malinowski 1922: 393).

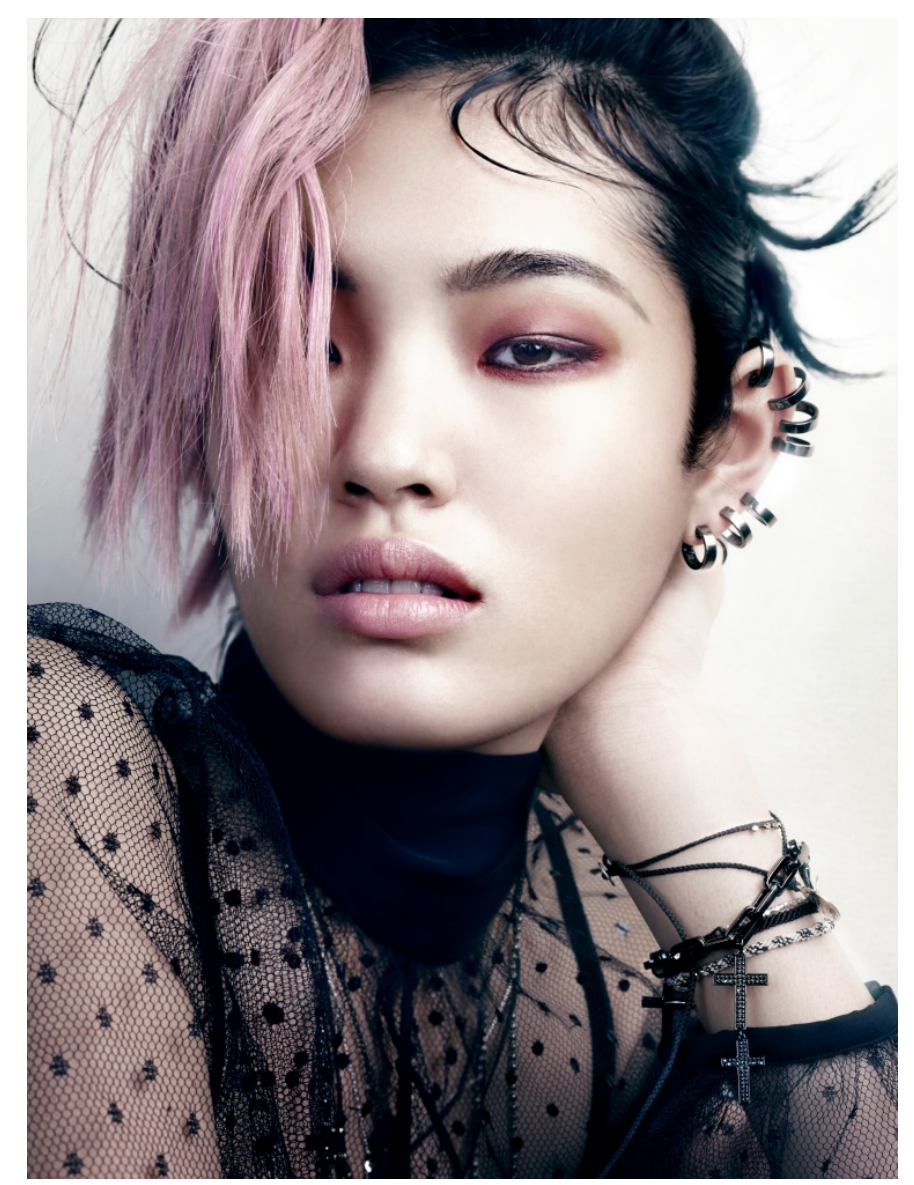

Figure 10: Metallic rings give an added sharpness (Chiharu Okunugi by David Slijper, for Vogue Nippon, October 2013)

\section{Fashion and Uncertainty}

But why is fashion marked by such magical practices and representations? Because the fashion world is marked by uncertainty-uncertainty about how best you can be "in fashion"; uncertainty about whether a collection will sell or not (what Richard Caves [2000: 3] refers to as a "nobody knows" economic property); uncertainty about what others in the fashion world will think of what you do and who you are-and magic both breeds and accompanies uncertainty (Malinowski 1954: 29-31; Gell 1992: 57). The 
magician aims to substitute what is uncertain with something that only he (or she) knows and makes public through magical action (When the cameras catch you, make sure you've got your best features on show-sleek, smooth hips and thighs). In fashion, as elsewhere, "magic happens in a world of its own, but this world is real to the natives. It therefore exerts a deep influence on their behaviour and so consequently is also real for the anthropologist" (Malinowski 1935: 215).

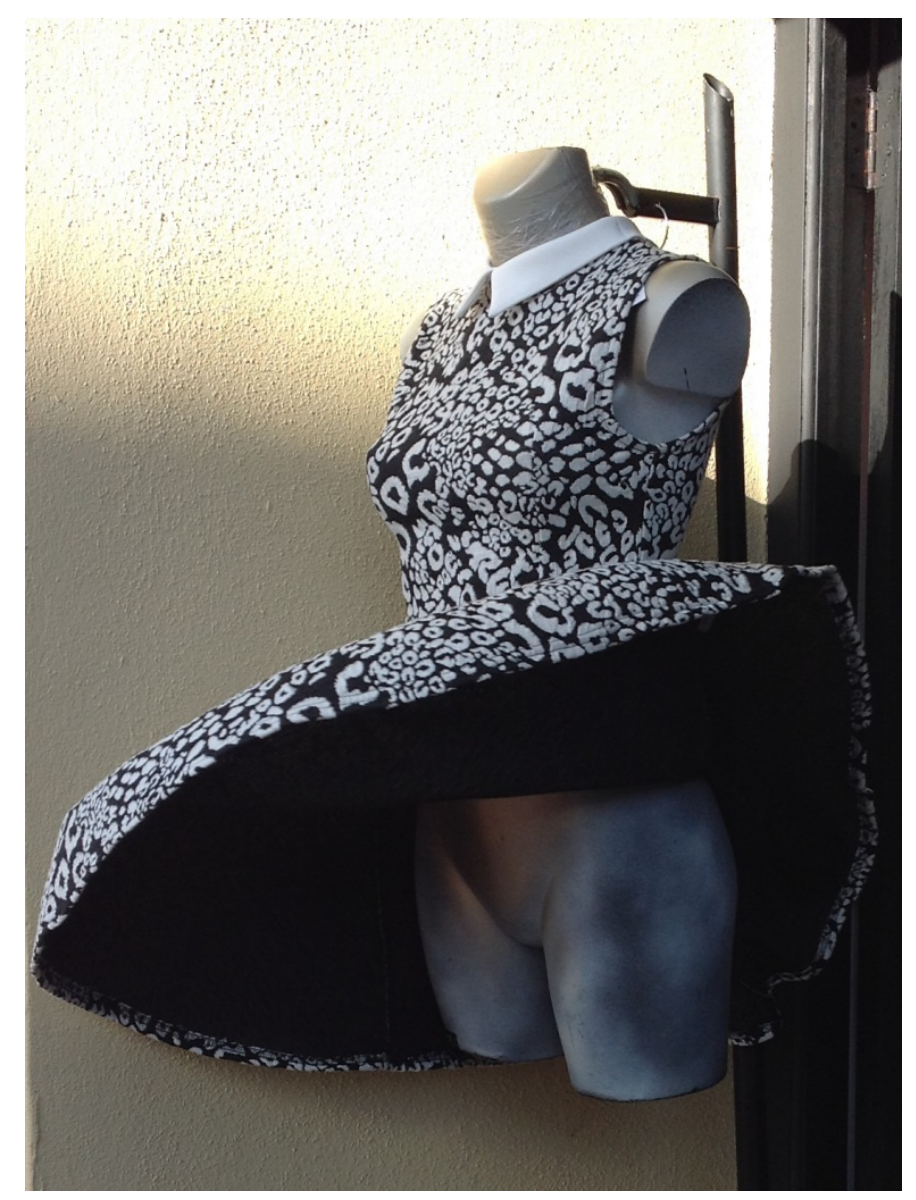

Figure 11: Sleeves are magic. Now you see them. Now you don't (photo by Brian Moeran).

Paradoxically, one way to overcome uncertainty is by revealing what is otherwise not there. This is the task of both magic and the fashion magazines (Sleeves are magic. Now you see them. Now you don't.) (Figure 11), which make the invisible visible by means of secrets, illusions, tips, and tricks (celebrity tips and tricks revealed). By exposing what goes on behind the scenes in the fashion world, fashion magazines heighten the mystery of fashion and make its magic work (Taussig 2003: 273; A new exhibition at the V\&A reveals the secret life of the fashion shoot). (Figure 12) As part of 
their revelation function, they frequently stress reincarnation-of a fashion item (the rebirth of the twinset), a style (replaying classic Parisian chic), or person for whom "the gift of rebirth" acts as magical potion and antidote to the perennial problem of ageing (Every day your skin is reborn through the wonder of SK-ii).

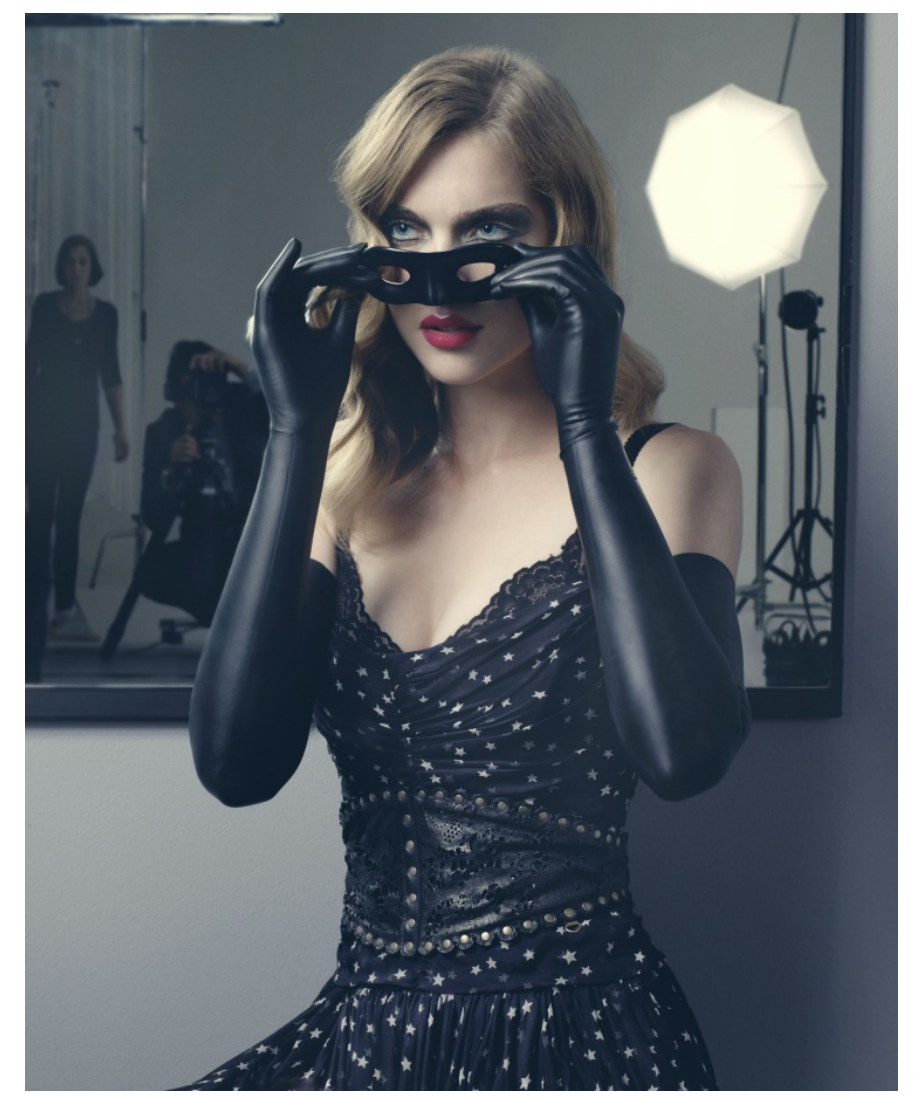

Figure 12: A skilled revelation of skilled concealment (Kim Noorda by David Slijper, for Elle UK, September 2011).

Fashion magazines also effect transformations both of clothes and of their wearers (a luxe silk shirt in midnight blue makes the ideal transformational piece). Such transformations involve metamorphosis (It's all about metamorphosis and transformation) and renewal consistent with the very idea of fashion (With strong shoulders and belted waists, the season's patterned and printed coats reinvent the silhouette). Mostly, these go together (Beauty-your instant makeover), although they should be effected in the right way by the right magician (Don't let just anybody transform your body).

That it is indeed magic that is offered to readers can be found in the various headlines offered by fashion magazines: Fashion in Wonderland; 9 quick tricks to boost 
your bust; What is your allure?; Designers conjure a bewitching painted paradise; and so on. Not only this, but they go beyond particular instances of magical rites to create a general aura of magic in the fashion world. In Pukka Party, for example, we learn that "Cartier International Polo at Windsor Great Park was one of the most glamorous events of the year. Not only did Cartier command a star-studded guest list, they somehow arranged for the sun to make a brief appearance, too."10 As John Middleton (1967: ix) noted many years ago:

"The realm of magic is that in which human beings believe that they may directly affect nature and each other, for good or for ill, by their own efforts (even though the precise mechanism may not be understood by them), as distinct from appealing to divine powers by sacrifice or prayer" (After equestrian chic, a pastoral mood is breezing into fashion). (Figure 13)

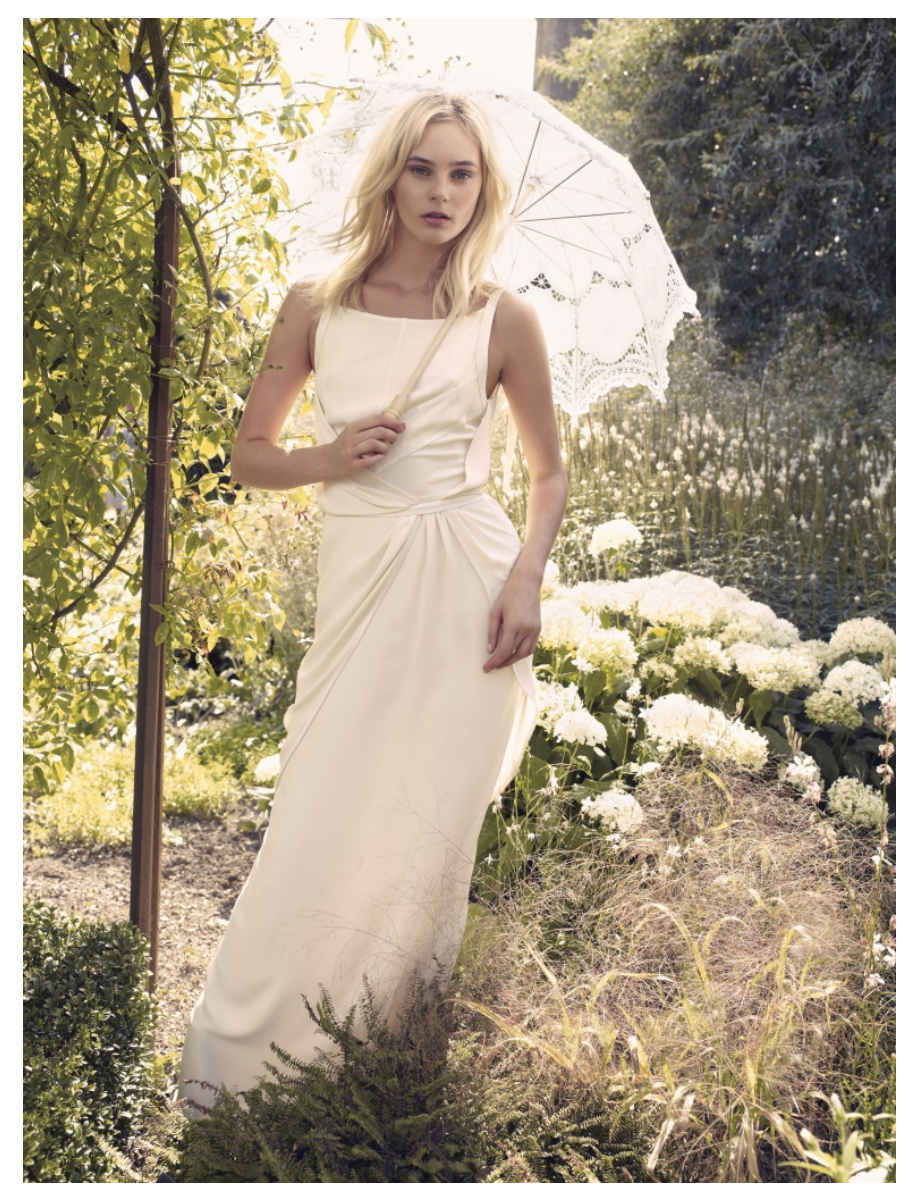

Figure 13: After equestrian chic, a pastoral mood is breezing into fashion (Juju Ivanyuk by David Slijper, for Harper's Bazaar UK, December 2013) 


\section{Magic and Cultural Production}

The argument presented here is that fashion constitutes a system of magic, in the sense that it employs some of its practitioners as magicians, who transform ordinary items of dress in such prescribed rites as the fashion show and the "fashion stories" published in fashion magazines. To help them in this task of metamorphosis and to consecrate them as "Fashion," fashion magazines make use of verbal spells to transmit the particular virtues of an object (elegant pencil skirt, rejuvenating skin moisturizer, sensual perfume) to its user. Such spells are a form of both sympathetic magic, in that they name qualities that the products then bring about, and contagious magic, in that, once named, such products maintain a lasting connection between maker and user (the delicate glamour of Gaultier's pleat-bust dress).

The three elements that make up this magical system-magicians, rites, and spells or representations-operate simultaneously in a number of different spheres of the fashion world. Fashion photographers work with fashion models in a controlled environment out of which, they hope, an unexpected "moment of magic" will appear. Fashion designers, in conjunction with their muses, look for equally unpredictable moments of "inspiration" to guide their work. Editors and art directors agonize over their choice of topics, images and words in putting together every issue of their fashion magazine. Everyone is intent upon making a name, because names-the names of celebrities, designers, fashion houses, photographers, models, titles, and brands, in particular-detach themselves from the physical world of people and things and, like fragrance, circulate magically in the air (Munn 1985: 114-8; Moeran 2014: 208-13).

Throughout history, magic has accompanied uncertainty of whatever kind, in whatever part of the world. People adopt magical technologies of enchantment when skill alone does not guarantee a successful outcome (a miracle of construction). (Figure 14) In analysing fashion magazines and the fashion system in terms of magic, I have relied on anthropologists' insistence that it is uncertainty that forces people to resort to magical practices, "begotten by the union of man's steadfast desire with the wayward whim of chance" (Malinowski 1954: 85). Uncertainty is at the core of fashion and-indeed-of all forms of cultural production, since "nobody knows" whether any creative product is ever going to be successful financially, aesthetically, or socially.

Financially, until a particular product is placed before a consumer, it is not at all certain how s/he will react to it because it is an "experience good." Market research can 
be undertaken, of course, to find out, but still success is unpredictable. This financial "uncertainty principle" is accompanied by another of what we may broadly define as "aesthetics." Magazine editors, stylists, photographers, fashion designers, and other creative personnel can rarely-if ever-be pinned down beforehand about the aesthetic choices that go into the structuring of a fashion magazine issue, the shooting of a fashion well, the selection of a model, and so on. They may, like Mario Testino, try to stage things beforehand, but they are in fact looking for "unpremeditated magic" to make things happen (Obrist 2012). As Orson Welles once remarked of film: "As a film director I preside over uncertainty."

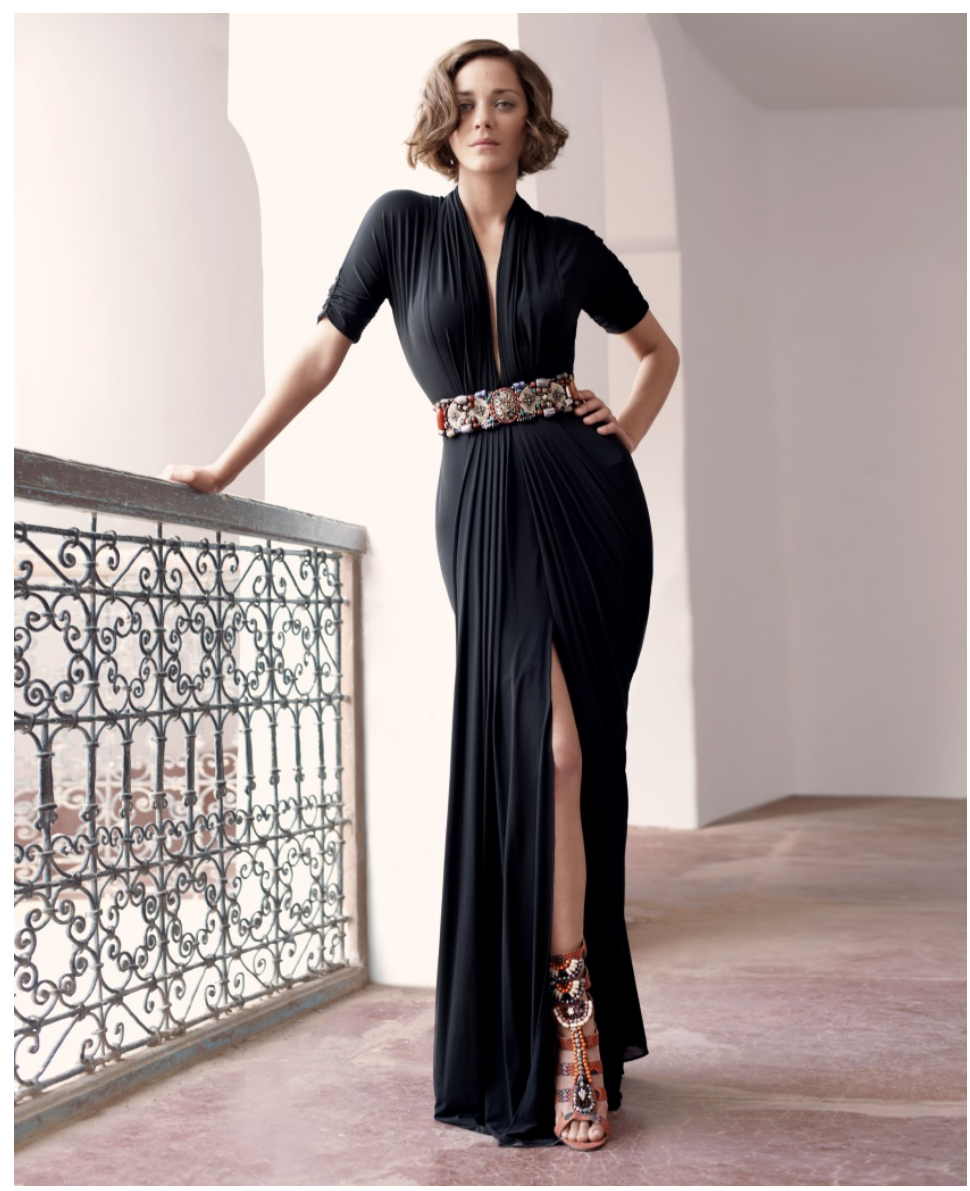

Figure 14: A miracle of construction (Marion Cotillard by David Slijper for Madame Figaro France, December 2009)

This aesthetic uncertainty (what Richard Caves [2000] refers to as the art for art's sake property) stems in large part from the often unanticipated transformations that occur as mental concept takes on two- or three-dimensional form and is then reused with its own internal transformations (A flourish of feathers turns a semi-long coat 
utterly seductive). (Figure 15) The fact that nobody is ever quite sure about how an inner vision will materialise in a product (Moeran 2014) explains both financial and aesthetic uncertainty, and also adds to the finished product's perceived magical quality.

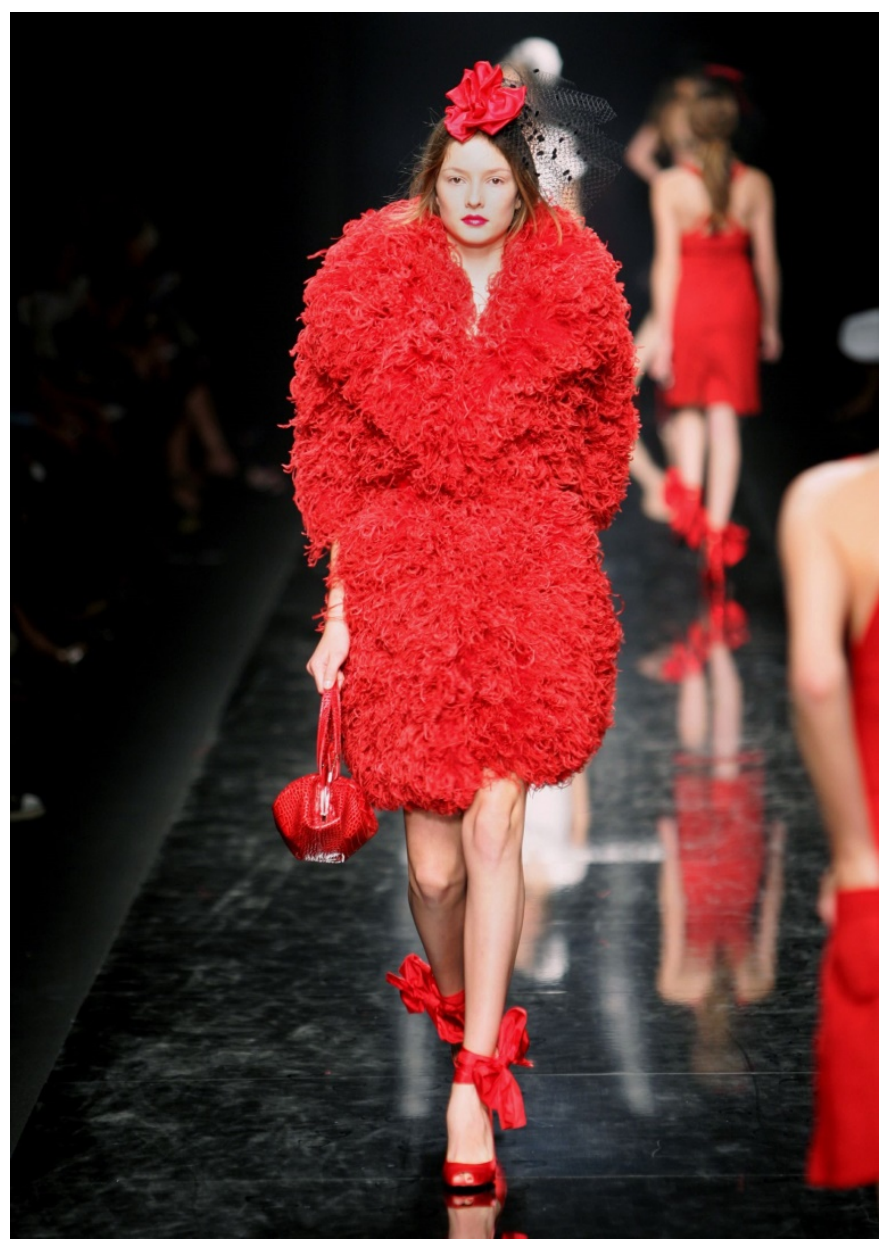

Figure 15: A flourish of feathers turns a semi-long coat utterly seductive (Photo by Frédérique Doumoulin, 2006. Courtesy of Sonia Rykiel)

Like all forms of cultural production, editing a fashion magazine requires careful coordination of the diverse skills of editors, make-up artists, photographers, publishers, layout artists, advertising managers, hair stylists, models, and so on and so forth. This is what Caves refers to as a motley crew property. With every step along the way to completion, all the necessary personnel must come together and do their necessary work within an allotted time frame. This involves considerable negotiation among the different creative people about how best to persuade their audience of the efficacy of their magical practices. Although all forms of cultural production are subject to 
hierarchical forms of management, there is still a lot of room for manoeuvring with regard to what the final product will look like, so that social uncertainty also prevails.

Another thing about cultural production generally is that-because neither financial, nor aesthetic, nor social success is guaranteed-fashion, film, music, publishing, video games, and other industries come up with an infinite variety of cultural products. This refers to "the array of actual creative products" available to consumers, on the one hand, but also, on the other, to "the universe of possibilities from which the artist chooses" (Caves 2000: 4). Infinite variety guarantees the success of at least some magical practices, even if all others fail, and so sustains belief in the system of magic as a whole, if not in individual magicians whose popularity waxes and wanes in accordance with perceived successes and failures in performance.

Because of the uncertainty of both demand and supply (in terms of the aesthetic choices made, combinations of personnel, and so on), and because cultural products differ in the quality of skills they display, the fashion world-like other worlds of cultural production-negotiates a ranking (what Caves refers to as $A$ list/B list) of designers, photographers, models, hair stylists, makeup artists, associated celebrities, magazine titles, brands, and so on. Internally, this ranking of talent has the effect of highlighting one style of magical practice over another (as well as accompanying economic rewards for services rendered); externally, it is used to overcome the uncertainty of market demand (through the manufacture of "names"). This uncertainty ensures the rapid turnover of peripheral magical personnel, like fashion models, editorial assistants of one sort or another, and celebrities. In other words, magic not only arises out of, but itself comprises, uncertainty. To overcome it just add attitude. 


\section{Acknowledgement}

I would like to thank the photographer, David Slijper (www.davidslijper.com) for allowing me to reproduce a number of his fashion magazine photographs here, as well as in my book, The Magic of Fashion.

\section{Notes}

1 The research on which this article is based lasted from 1990 to approximately 2005. During this time, I took out subscriptions and collected more than 600 copies of Elle, Harper's Bazaar, Marie Claire, and Vogue in France, Hong Kong, Japan, the UK, and USA, plus, more sporadically, editions in Greece, India, and other parts of the world. I also talked to editorial and publishing staff at the four publications in question in Hong Kong, London, New York, Paris, and Tokyo. For further discussion of methodology and a more detailed analysis of international fashion magazines, see Moeran (2015).

2 The ways in which clothes and materials are described in fashion magazines (sexy silk, frivolous chiffon, soft knits and so on) echo Evans-Pritchard's discussion of magic among the Azande, for whom "material substance...is the occult and essential element in a rite, for in the substance lies the mystical power which produces the desired end" (1947: 441). Fashion magazines, like Zande magicians, address their materials and then the object that they wish to influence (ibid. p. 450), leading to such phrases as Languid shapes speak of intimacy, personality, and a dark sense of cool, or Gleaming gilded leather, sparky sequins and lashings of Lurex add film-star glamour to this summer's wardrobe. ${ }^{3}$ Many of the words cited here, like glamour soon to be discussed, owe their etymological origins to forms of magic. Pretty, for example, once meant "cunning, skilful, and artful," and is derived from prættig meaning trick or wile; fascinate meant to bewitch, or enchant (fromLatin fascinum meaning spell or witchcraft); allure to attract, tempt, or captivate, primarily through "a gait, way of walking"; and charm referred to a magical incantation or spell (Oxford Dictionary of English). 
${ }^{4}$ More recently, Delphine Dion and Eric Arnould (2011) have argued that luxury retail strategy in the fashion world relies on art and magic to create brand charisma. See Arnould's contribution to this issue of Anthropology Today.

${ }^{5}$ Fashion magazines make use of both illocutionary (a different kind of cool) and perlocutionary (grey suddenly looks newly fresh and chic) acts. The former are designed to "secure uptake" on the part of their readers and the fashion world, thereby taking effect and inviting a response (Austin 1975: 117-8; low-key cool) which leads into the next fashion "season" with its collections (a dark sense of cool), and so on (colour-strong colour-is now cool) ad infinitum.

${ }^{6}$ Fashion magazines publish fashion photographs in order to achieve, through nonlocutionary means, the response (or sequel) invited by their perlocutionary acts (Austin 1975: 119).

7 I use the term "ensemblages" in association with technologies of enchantment, because enchantment in the fashion and beauty industries takes place at several different levels, involving ensemblages of, often overlapping, personnel who perform their magical practices together at different points in the fashion world value chain for different audiences and thereby establish worth (Moeran 2014: 82-100).

${ }^{8}$ As Hoskins (2014: 10) notes: "It is everything that goes around clothes that makes them fashion."

9 The same holds true for fashion photographers, makeup artists, hair stylists, and others working in the fashion world (see, for example, Bowles 2014; Lennard 2007; Obrist 2012).

10 “People in Vogue.” Vogue UK, October 2000.

\section{References}

Appadurai, Arjun 2016 Banking on Words: The Failure of Language in the Age of Derivative Finance. Chicago: University of Chicago Press.

Associated Press 2009 “Michael Jackson glove sells for \$350,000.” Today, December 1. http://www.today.com/id/34084928/ns/today-today entertainment/t/michaeljackson-glove-sells/\#.Uy mBaOwrcs

Austin, J. L. 1975 (1962) How to Do Things with Words. 2nd Edition. Edited by J. 0. Urmson and Marina Sbisà. Oxford: Oxford University Press. 
Bourdieu, Pierre 1980 "The production of belief: contribution to an economy of symbolic goods." In Media, Culture \& Society: A Critical Reader, Volume 2, trans. Richard Nice, pp. 261-293. London: Sage Publications.

1993 The Field of Cultural Production: Essays on Art and Literature. Edited and introduced by Randal Johnson. Cambridge: Polity Press.

Bowles, Hamish 2014 "Fine feathers." Vogue USA, September, p. 596.

Caves, Richard 2000 Creative Industries: Contracts between Art and Commerce.

Cambridge, MA: Harvard University Press.

Crane, Diana 2000 Fashion and its Social Agendas. Chicago: University of Chicago Press.

Davies, Owen 2012 Magic: A Very Short Introduction. Oxford: Oxford University Press.

Dion, Delphine and Eric Arnould 2011 "Retail luxury strategy." Journal of Retailing 87

(4): 502-520.

Entwistle, Joanne 2000 The Fashioned Body. Cambridge: Polity Press.

----- and Agnès Rocamora 2011 "Between art and commerce: London Fashion week as trade fair and cultural spectacle." In Negotiating Values in the Creative Industries: Fairs, Festivals, and Competitive Events, edited by Brian Moeran and Jesper Strandgaard Pedersen, pp. 249-269. Cambridge: Cambridge University Press.

Evans-Pritchard, E. E. 1937 Witchcraft, Oracles and Magic among the Azande. Oxford: Clarendon Press.

Flügel, John 1950 The Psychology of Clothes. London: Hogarth Press.

Frazer, J. G. 1990 The Golden Bough. London: Macmillan.

Gell, Alfred 1988 "Technology and magic." Anthropology Today 4 (4): 6-9.

--_-_ 1992 "The technology of enchantment and the enchantment of technology." In Anthropology, Art and Aesthetics, edited by Jeremy Coote and Anthony Shelton, pp. 40-66. Oxford: Clarendon Press.

Geertz, Clifford 1983 Local Knowledge: Further Essays in Interpretive Anthropology. New York: Basic Books.

Gmelch, George 1985“Baseball magic.” In Magic, Witchcraft, and Religion: An Anthropological Study of the Supernatural, edited by Arthur C. Lehmann and James L. Myers ( $5^{\text {th }}$ Edition). Mountain View, CO: Mayfield Publishing Company.

Gundle, Stephen and Clino T. Castelli 2006 The Glamour System. Basingstoke: Palgrave Macmillan.

Hermes, Joke 1995 Reading Women's Magazines. Cambridge: Polity Press.

Hoskins, Tansy 2010 Stitched-Up: The Anti-Capitalist Book of Fashion. London: Pluto Press.

Jackson, Michael 2005 Existential Anthropology: Events, Exigencies, and Effects. Oxford: Berghahn.

Lennard, Erica 2007 (1980) “Doing fashion photographs." In Fashion Theory: A Reader, edited by Malcolm Barnard, pp. 527-33. London and New York: Routledge. 
Lévi-Strauss, Claude 1966 The Savage Mind. Chicago: University of Chicago Press.

Lipovetsky, Gilles 1994 The Empire of Fashion: Dressing Modern Democracy. Princeton, NK: Princeton University Press.

Malinowski, Bronislaw 1922 Argonauts of the Western Pacific. London: Routledge \& Kegan Paul.

----- 1935 Coral Gardens and Their Magic. Volume 2. London: Allen \& Unwin.

--_-- 1954 (1948) Magic, Science and Religion, and Other Essays. New York: Anchor.

Mauss, Marcel 1972 A General Theory of Magic.

McCreery, John 1995 "Malinowski, magic and advertising: on choosing metaphors." In Contemporary Marketing and Consumer Behavior, edited by John Sherry Jr., pp. 309329. Thousand Oaks, CA: Sage.

McRobbie, Angela 1998 British Fashion Design: Rag Trade or Image Industry? London and New York: Routledge.

Middleton, John 1967 "Introduction." In Magic, Witchcraft \& Curing, edited by John middleton, pp. 1-27. Austin, TX, and London: University of Texas Press.

Moeran, Brian 2014 The Business of Creativity: Toward an Anthropology of Worth. Walnut Creek, CA: Left Coast Press.

--_-- 2015 The Magic of Fashion: Ritual, Commodity, Glamour. Walnut Creek, CA: Left Coast Press.

Morin, Edgar 1972 The Stars. Minneapolis, MN: University of Minnesota Press.

Munn, Nancy D. 1986 The Fame of Gawa: A Symbolic Study of Value Transformation in a Massim (Papua New Guinea) Society. Durham and London: Duke University Press.

Obrist, Hans-Ulrich 2012 “An interview with Mario Testino.” In Mario Testino: Todo o Nada. Lima, Peru: Asociación Mario Testino.

Pels, Peter 2003 "Introduction." In Magic and Modernity: Interfaces of Revelation and Concealment, edited by Birgit Meyer and Peter Pels, pp. 1-38. Stanford, CA: Stanford University Press.

Powdermaker, Hortense 1951 Hollywodd, the Dream Factory: An Anthropologist Looks at the Movie-Makers. London: Secker \& Warburg.

Steele, Valerie 1991 “The F word.” Lingua Franca, April 1991.

Stein, Philip L. and Rebecca Stein 2005 The Anthropology of Religion, Magic and Witchcraft. Upper Saddle River, NJ: Prentice Hall.

Taussig, Michael 2003 "Visceraloity, faith and scepticism: another theory of magic." In Magic and Modernity: Interfaces of Revelation and Concealment, edited by Birgit Meyer and Peter Pels, pp. 272-306. Stanford, CA: Stanford University Press.

Wax, Murray and Rosalie Wax 1963 "The notion of magic." Current Anthropology 4 (5): 495-518.

Wilson, Elizabeth 1987 Adorned in Dreams. London: Virago. 